\title{
THE ENTOMOLOGIST.
}

\begin{tabular}{l|l|l} 
No. I. & NOVEMBER, MDCCCXL. & PRICE 6D.
\end{tabular}

\section{Art. I. - Entomological Notes. By Edward Newman.}

(Continued from the 'Entomological Magazine', vol. V. p. 402).

Class.-Coleoptera.

Natural Order.-Cerambycites, Newman.

Genus.-Callisphyris, Newman.

CAPUT pronum, prothorace angustius; antennæ dimidio corporis vix longiores, 11-articulatæ, simplices, apice paullò crassiores : prothorax lateribus medio dentatis : elytra dimidio corporis manifestò breviora, a basi ad medium pedetentìm angustata, ponè medium linearia: pro- et mesopedes breves, simplices, femoribus haùd tumescentibus; metapedes elongati, femoribus tibiisque valdè hirsutis.

Call. Macropus. Niger, hirsutus, antennarum basi, elytris, pedibusque flavis: metafemorum spatio mediano, tarsisque omnibus nigris. (Corp. long. 1 unc. lat. '35 unc.)

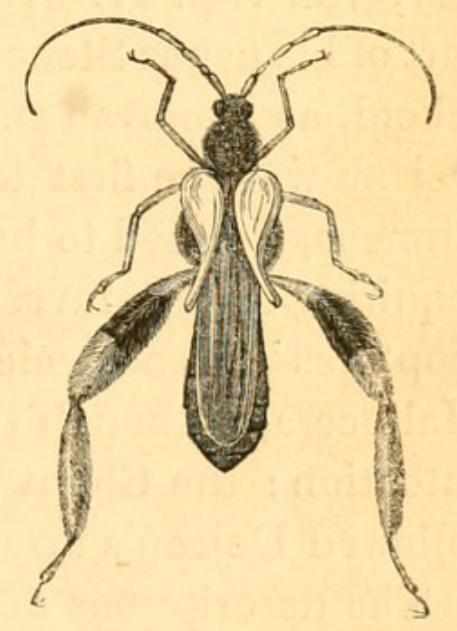

Inhabits South America. A single specimen, taken by Mr. Darwin on the Island of Chilöe, is in the cabinet of the Entomological Society of London.

This fine insect in some of its characters closely resembles Odontocera of Serville, but the structure of its antennæ, the tooth on each side of its prothorax, and its slender and simple pro- and meso-femora, incline me to consider the similarity merely dependant on its narrowed elytra and hirsute metatibiæ, and not implying any very near approach to that well-known genus. 


\section{Family.-Phoracanthide, Newman.}

In this family I would propose to include Phoracantha of Newman, Mallocera, Sphærion, Cordylomera, Trichophorus, and Elaphidion of Audinet-Serville, and several other nearly-allied insects, many of which are at present undescribed. They are generally to be distinguished at the first glance by having a short spine at the extremity of several joints of the antennæ, beginning with the third and usually ending with the seventh: the head is porrected, nearly on a level with the prothorax, and not deeply received into that part as in some of the families of this extensive order. The elytra are generally terminated by an oblique truncature, of which the exterior angle is usually furnished with an acute spine. I have not given the name Phoracanthidæ in compliment to a genus of my own, but because that genus is the type of the family, now for the first time collected together or in any way indicated, and because the name is expressive of the principal character by which the family is distinguished.

\section{Genus.-Phoracantha, Newman.}

The genus Phoracantha is described in the 'Annals of Natural History,' vol. v. p. 17. It had previously been regarded by Fabricius as part of his genus Stenocorus; and the earlier entomologists of the same school, as Donovan and Kirby, followed in his footsteps. The Count Dejean was the first to break up a genus, which, like Chrysomela of Linneus, seemed to be used by its author as a receptacle for sundries requiring further investigation, and we find in the 'Catalogue des Coléoptères ' three species of Phoracantha placed under Serville's genus Mallocera, although the last-mentioned author has indicated no such intention: the Count de Castelnau, in his 'Animaux Articulés,' has followed Dejean's arrangement.

The descriptions of the following species, the first only excepted, were ready for publication nearly two years ago. In January last they were actually on their way to the printer's when I heard that Mr. Hope was at work on the same group: I instantly withdrew my descriptions, lest my species should clash with his. Mr. Hope's paper has subsequently been read at the Zoological Society, and he does not appear to possess a single species that I have described. The previously-described species of Phoracantha are, 1, synonyma of Newman, 'Ann. Nat. Hist.' l. c., synonymous with Stenocorus punctatus of Kirby, 'Trans. Linn. Soc.' xii. 471; 2, punctata of Donovan's 'Epitome of the Insects of New Holland;' 3, tenebrosa of Newman, synony- 
mous with Sten. obscurus of Donovan, but not with Sten. obscurus of Fabricius, 'Syst. Eleu.' ii. 307; 4, semipunctatus of Fabricius, Olivier, and Donovan, but not of Boisduval ; 5, rubripes of Boisduval, 'Faune de l'Océanie,' i. 477; 6, dorsalis of MacLeay, 'Appendix to King's Voyage,' ii. 451: and 7, biguttata of Donovan, which Mr. Hope, in the 'Transactions of the Zoological Society of London,' i. 107, gives as the type of Latreille's genus Tmesisternus, and which Dejean and Castelnau place under Serville's genus Mallocera. The last species differs in many respects from Phoracantha, Tmesisternus, and Mallocera, and is particularly to be distinguished by its slender and graceful form, its suddenly incrassated femora, and the gaiety of its colours. In this genus-making age it will doubtless be raised to generic honours ; in which case it may be called Callirhöe.

Phor. hamata. Antennæ corpore vix longiores; articulis $\mathbf{3 - 7}$ apice bispinosis : prothorax quàm in cæteris minor, angustior, brevior, dorso rugosus spatio mediano glabro, lateribus spinâ acutâ recurvâ armatus : elytra asperè ac profundè puncta; punctis apicem versus magnitudine pedetentim decrescentibus: color testaceus, oculis nigris ; elytra testacea fasciâ communi undatâ quasi VV ante medium maculâque communi suturali ponè medium fuscis. (Corp. long. 1·3 unc. lat. 375 unc.)

Inhabits New Holland. A single specimen, in the cabinet of the Entomological Club, was taken by Mr. Kirk at Sydney.

Phor. tricuspis. Antennæ corpore valdè longiores, apices gracillimæ, articulis $1-3$ apice 1 -spinosis: prothorax dorso rugosus, lateribus ponè medium dente obtuso armatus : elytra asperè ac profundè puncta; punctis apicem versus magnitudine pedetentìm decrescentibus : color fuscus nitidus ; elytra plagâ magnâ medianâ apicibusque luteis signata ; plaga mediana fasciâ angustâ undatâ interrupta est. (Corp. long. 1·4 unc. lat. '3 unc.)

Inhabits New Holland. A single specimen, in the cabinet of the Entomological Club, was taken by Dr. Stanger at Sydney.

Phor. quinaria. Antennæ corpore longiores, articulis 3-7 apice 1-spinosis: prothorax acnerè punctus, lateribus dente mediano acuto armatus: elytra asperè ac profundè puncta, punctis apicem versus magnitudine pedetentìm decrescentibus : color fuscus, singulo elytro maculis 4 apicibusque luteis. (Corp. long. 1 unc. lat. 25 unc.) 
Inhabits New Holland. A single specimen, in the cabinet of the Entomological Club, was taken by Mr. Davis at Adelaide.

Phor. recurva. Antennæ corpore longiores, quàm in cæteris hirsutiores, articulis $3-\mathbf{7}$ apice 1 -spinosis, spinâ tertii paullò recurvâ: prothorax complanatus, rugosus, spatiis tribus elevatis glabris; lateribus spinâ acutâ armatus : elytra basi asperè ac profundè puncta, apice glaberrima: color fusco-ferrugineus, antennis pedibusque luteo-testaceis; elytra lutea, maculâ sive lineâ obliquâ utrinquè ante medium, fasciâque latissimâ ponè medium fusco-ferrugineis. (Corp. long. $1 \cdot 2$ unc. lat. $\cdot 3$ unc.)

Stenocorus semipunctatus. Boisduval, 'Faune de l'Océanie,' p. 476.

Inhabits New Holland. This beautiful insect is common in all our collections under the name of Stenocorus semipunctatus.

Phor. aberrans. Antennæ corpore vix longiores, articulis 3-6 apice 1-spinosis : prothorax elongatus capite duplò longior, dorso tuberculatus, lateribus 1-dentatus: elytra puncta punctis apicem versus minutis : color fusco-ferrugineus fasciâ latâ fusco-nigrâ ponè medium, ante fasciam maculis obliquis incertis luteis interruptus, subtùs fuscus. E præcedentibus differt gracilitate majori, at planè ejusdem generis. (Corp. long. 75 unc. lat. $\cdot 175$ unc.)

Inhabits New Holland. There is a single specimen in the cabinet of the British Museum.

Phor. allapsa. Antennæ corpore vix longiores, articulis 3-6 apice 1-spinosis : prothorax elongatus capite duplò longior dorso tuberculatus, lateribus vix dentatus, tubere minuto mediano instructus : elytra puncta, punctis apicem versus minutis : color fuscus; elytra maculis 7 elongatis albidis ornata; maculæ sic dispositæ, 3, 3, 1. Sternum abdominisque segmentum primum ferruginea, segmenta cætera nigra. (Corp. long. 7.5 unc. lat. $\cdot 175$ unc.)

Inhabits Van Dieman's Land. There is a single specimen in the cabinet of the British Museum.

Phor. senio. Antennæ corpore vix longiores, articulis 3-7 apice 1-spinosis: prothorax asperè punctus, lateribus dente obtuso armatus : elytra asperè ac profundè puncta, punctis apicem versus magnitudine pedetentim decrescentibus: color fuscus, sin- 
guli elytri maculis 2 apiceque luteis. (Corp. long. $\cdot 6$ unc. lat. $\cdot 125$ unc.)

Inhabits New Holland. This pretty little insect is also common : Mr. Davis has sent it from Adelaide; Mr. Kirk and Mr. Imeson from Sydney.

\section{Genus.-Mallocera, Serville.}

The genus Mallocera of Serville, as originally described, contains but a single species, Mal.glauca: the Count de Castelnau has added a second, Mal. elongata, 'Anim. Articulés,' 70 livr. p. 424 : the same author also adds to the genus the Stenocorus biguttatus of Donovan. The species described below I believe to be new.

Mall. sericata. Antennæ corpore valdè longiores, basim versus quàm in cæteris crassiores : prothorax rugosus, dorso tuberibus 5 minutis instructus, lateribus dente magno obtuso vix recurvo armatus : color fuscus, lanugine sericatâ perpulchrâ gaudens. (Corp. long. $\cdot 95$ unc. lat. $\cdot 25$ unc.)

Inhabits Brazil. There is a single specimen in the cabinet of the British Museum.

\section{Genus.-Spherion, Serville.}

Serville has proposed the name Sphærion (in the 'Ann. Ent. Soc. of France,' iii. 68), for a division of his genus Elaphidion (Id. iii. 66), distinguished by the species having the elytra simply terminating without truncature, in a single spine. The type of the genus, Sph. cyanipennis, is from Rio. There are specimens in the cabinet of the British Museum.

\section{Genus.-Cordylomera, Serville.}

This genus is closely allied to the foregoing, but the known species inhabit Africa. The type, Cor.nitidipennis (described 'Ann. Ent. Soc.' iii. 24), is a very beautiful species ; there are specimens in the cabinet of the British Museum. Cerambyx spinicornis of Fabricius ('Syst. Eleut.' ii. 271), is referable to this genus.

\section{Genus.-Trichophorus, Serville.}

The species lippus of Germar, admirably described in that author's 'Insectorum Species,' p. 508, No. 677, is the type of Serville's genus Trichophorus, ('Ann. Ent. Soc. of France,' iii. 17). The species obli- 
quus, which is the type of the second division of Trichophorus, does not appear to me to be one of the Phoracanthidæ. The following species is, I believe, undescribed, and although so very similar to Tric. lippus, I think it is distinct.

Tric. distinctus. Ferrugineo-fuscus maculis numerosis albo-tomentosis : prothorax et elytra asperè puncta. (Corp. long. 85 unc. lat. $\cdot 2$ unc.)

The entire colour of this insect is darker than Tric. lippus, it is also more rugose and less shining, and the white markings on the elytra are not surrounded with a black margin: the white markings are thus distributed; on the crown of the head are two parallel longitudinal lines; a spot occupies the space between the eye and antenna; on the posterior part of the prothorax is a longitudinal line on each side, each of these joins a marginal transverse line; the scutellum is white: each elytron has three longitudinal lines; the 1st is near the suture and above the middle of the elytron; the 2nd is exterior to the 1st, on a level with the termination of which it commences, it is broken in the middle; the 3rd is exterior to the 2 nd, and extends below it, being the longest of the three. Both the species are from Brazil, and are in the cabinet of the Entomological Club.

\section{Genus.-Elaphidion, Serville.}

The genus Elaphidion was established by Audinet-Serville, in the 'Annales Soc. Ent. of France,' iii. 66. It contains a great number of species, very similar in general appearance, and all of them inhabitants of the New World. The characters by which it is distinguished from the foregoing are slight; the prothorax is rounded laterally, and is without spines; above, it is flattened: the elytra are obliquely truncate, and bear a spine at each angle of the truncature. The typical species is Stenocorus spinicornis of Fabricius, 'Syst. Eleu.' ii. 306. The following species I think is hitherto undescribed.

Elaph. deflendum. Antennæ corpore paullò longiores, caput parvum, anticè acuminatum: prothorax glaber: elytra parcè ac profundè puncta, apice vix spinosa : color niger, prothorax lætè rufus maculâ magnâ rotundâ dorsali nigrâ: scutellum lanugine albidâ densè tectum : totum insectum pilis albidis sparsis irroratum. (Corp. long. 5 unc. lat. 1125 unc.)

Inhabits the United States of North America. A specimen in the cabinet of the Entomological Club, was taken in Georgia. 


\section{Genus.-Mallosoma, Serville.}

This genus is closely allied to the preceding: Serville ('Ann. Soc. Ent. of France,' iii. 68) has scarcely assigned it a single character by which to distinguish it; he has indeed described the termination of the elytra as unarmed, which is erroneous, the exterior angle of the truncature having an obvious spine. A beautiful species, Mallosoma elegans, is common in Brazil, and is found running over the trunks and leaves of trees, and flying readily, after the manner of a Clytus, close to which genus it has been placed by the Count Dejean. The following species I think is not previously described.

Mall. fuligineum. Fuligineum, obscurum, lanugine nigrâ densè tectum : prothorax ferrugineus, maculâ magnâ rotundatâ dorsali lineâque laterali nigris : elytra immaculata. (Corp. long. 5 unc. lat. 175 unc.)

Inhabits Brazil. A single specimen is in the cabinet of the Entomological Club.

\section{Genus.-Phacodes, Newman.}

Caput ferè pronum : antennæ graciles corpore paullò breviores, pilosæ, 11-articulatæ, articulis $3-5$ apice 1-spinosis: prothorax ferè cylindraceus lateribus rotundatus inermis, dorso tuberibus tribus glabris instructus : elytra ampla, convexa, apice rotundata, apice ipso truncato, angulo exteriori 1 -spinoso: pedes mediocres.

Phac.lentiginosus. Facies Callidii : prothorax rugosus : elytra puncta, quoque pustulata; punctis basim versus crebriores: pustulis passìm dispositis. Color fuscus, fasciâ ponè medium valdè indistinctâ lanuginosâ albidâ. (Corp. long. $1 \cdot 2$ unc. lat. $\cdot 375$ unc.)

Inhabits New Holland. In the cabinet of the Entomological Club.

This large and abundant insect seems to have been unknown to Boisduval and MacLeay. Its appearance is that of a large Callidium; in some of its characters it displays an obvious affinity to the Phoracanthidæ.

\section{Genus.-Cyllene, Newman.}

Facies Clyti: caput parvum, ferè pronum, antennæ maris corpore longiores, femince valdè breviores, 11-articulatæ; articulis externis manifestò crassioribus, $3-6$ apice spinâ brevi armatis : prothorax latus, 
dorso convexus, lateribus rotundatis dente postico armatis: elytra convexa, apice 1-spinosa: pedes simplices.

Cyll. spinifera. Fusca, obscura, lanuginosa: prothorax maculis duabus glabris ornatus: antennarum articuli basi cinerei : elytra fusca, maculis fasciisve lanuginosis cinereis ornata. (Corp. long. $\cdot 7$ unc. lat. $\cdot 225$ unc.)

Inhabits South America. Specimens taken by Mr. Darwin are in the cabinet of the Entomological Society. I find no description of this insect in Serville's 'Nouvelle Classification,' but it is by no means uncommon in collections : it bears as close a resemblance to Clytus as Phacodes to Callidium.

The descriptions which follow have no reference to any particular family of Longicorns, but are simply recorded as supposed novelties to the science.

\section{Genus.-CEmona, Newman.}

Facies ferè Clyti : caput vix pronum, in prothorace ad oculos ferè immersum, anticè elongatum; oculi reniformes subtùs dilatati : antennæ corpore vix longiores, filiformes, 11-articulatæ, articuli 3us 4usque sequentibus paullò breviores: prothorax inermis, latitudine longior, lateribus ferè parallelis, disco transversè rugatus : elytra dorso complanata, apicem versus pedetentìm attenuata, apice ipso rotundato: pedes paullò elongati, femoribus simplicibus.

Emona humilis. Castanea, oculis, femoribus apice tarsisque fuscis : vertex pilis aureis crebrè obsitus, medio lineâ glabrâ longitudinalitèr divisus: scutellum tomentosum cinereum : elytra profundè puncta, pilis canis obsita. (Corp. long. 55 unc. lat. -125 unc.)

Inhabits New Zealand. A single specimen, taken by Mr. Darwin, is in the cabinet of the Entomological Society of London.

\section{Genus.-OEme, Newman.}

Caput exsertum, transversum ; antennæ graciles, corpore breviores, pilosæ, spinis minutis passìm instructæ: prothorax ferè globosus, inermis : elytra elongata, prothorace latiora, linearia, apice rotundata: pedes simplices, femoribus paullò compressis.

Eme indecora. Testaceo-fusca, unicolor, oculis tantùm nigris : 
prothorax punctus: elytra puncta lineis elevatis duabus instructa. (Corp. long. '6 unc. lat. $\cdot 125$ unc.)

Inhabits North America. A single specimen in the cabinet of the Entomological Club, was taken by Mr. E. Doubleday, at St. John's Bluff, in East Florida. It approaches in habit to Xystrocera globosa.

\section{Genus.-Petalodes, Newman.}

Antennæ corpore breviores, lamellatæ, 11-articulatæ, articulus 1us mediocris exteriùs crassior, 2us brevissimus, 3us et sequentes breves, ramulam longissimam emittentes: oculi maximi, infra capitem dilatati, ferè conniventes: prothorax capite haùd latior, paullò longior, nullo modo armatus : elytra linearia prothorace paullò latiora, triplò longiora, apice inermia.

Peta. laminosus. Punctus, fuscus, scu-

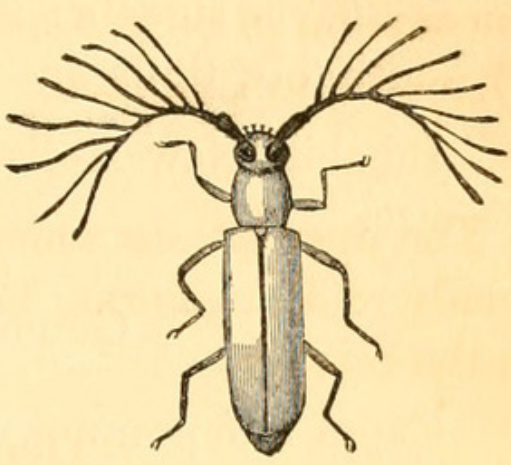
tello, lineâque laterali latâ pro- mesoet metathoracis albis: abdominis segmentis lateralibus albo bimaculatis. (Corp. long. 8 unc. lat. $\cdot 2$ unc.)

Inhabits New Holland. A single specimen, taken by Mr. Davis at Adelaide, is in the cabinet of the Entomological Club.

\section{Genus.-Heterachthes, Newman.}

Generi Ibidioni (Serville) affinis : caput ferè porrectum; antennæ corpore longiores, 11-articulatæ; articulus lus mediocris, 2us brevis, 3us, 4us, 5us, et 6us elongati, cylindracei, incrassati, 7us, 8us, 9us, 10us, et llus elongati, filiformes : oculi magni, reniformes, ad antennarum basim emarginati: prothorax elongatus, cylindraceus, capite angustior, lateribus ferè parallelus : elytra linearia prothorace paullò latiora, apice ferè rotundata: pedes mediocres, femoribus vix tumidis.

Heterach.ebenus. Concolor, niger, opacus, antennarum articulis incrassatis tantùm nitidis. (Corp. long. 44 unc. lat. 075 unc.)

Inhabits North America. In the cabinet of the Entomological Club : taken by Mr. Doubleday in East Florida.

G. N.-Callidio affine.

piceum. Piceum, antennis pedibusque pallidioribus: antennæ corpore breviores, simplices: caput porrectum prothorace 
vix angustius: prothorax rugosus, lateribus inermis: scutellum parvum, cinereo-lanuginosum : elytra prothorace latiora, lateribus parallela, apice rotundata inermia, crebrè puncta; punctis profundis, basim versus confluentibus : femora apice manifestò haùd repente tumida. (Corp. long. 75 unc. lat. '2 unc.)

Inhabits New Holland. In the cabinet of the Entomological Club \&c.; not uncommon.

_ signiferum. Punctum, ferrugineo-fuscum : elytra maculis 11 flavis signata: femoribus apice tumescentibus basi attenuatis, luteis, tibiis quoque basi luteis. (Corp. long. 3 lat. 075 unc.)

Inhabits New Holland. A specimen in the cabinet of Mr. Waterhouse.

\section{Genus.-Hephestion, Newman.}

Caput ferè pronum, exsertum, prothorace haùd angustius : antennæ corpore breviores, apice paullò crassiores, 11-articulatæ: prothorax spinis 4 lineâ transversâ collocatis armatus: elytra apice inermia: pedes simplices, graciles, mediocres, metafemoribus tibiisque paullò compressis.

Hephces. ocreatus. Antennarum articuli 3us 4usque sequentibus breviores, nitidi : elytra linearia rotundata: caput, antennæ, prothorax et sternum nigerrima: elytra glaberrima, splendore metallico purpureo mutabili læta: pedes nigri, femoribus croceis : abdomen croceum, apice nigro. (Corp. long. 1 unc. lat. 25 unc.

Inhabits South America. A single specimen, taken by Mr. Darwin on the island of Chilöe, is in the cabinet of the Entomological Society of London.

Hephas. macer. Antennarum articuli 3us 4usque sequentibus haùd breviores, obscuri : elytra corpore breviora, à basi ad medium pedetentìm attenuata, post medium tenuissima, linearia: niger, antennarum articulis 1mo basi, 7 mo omninò, 8vo basi albidis : metafemoribus basi metatarsis medio albidis. (Corp. long. 85 unc. lat. $\cdot 15$ unc.)

Inhabits South America. A single specimen, taken by Mr. Darwin on the island of Chilöe, is in the cabinet of the Entomological Society of London. 


\section{Genus.-Trachyderes, Dalman.}

Trac. venustus. Piceus, elytrorum fasciis duabus, maculâque singuli subrotundâ apicali lætè stramineis: scutellum elongatum, sublineare, medio longitudinalitèr impressum, piceum. (Corp. long. 1.15 unc. lat. 5 unc.)

Inhabits Demerara. Three specimens of this lovely insect were taken by M. Schomburgk, who kindly allowed me to describe and name the species. The entire colour is pitchy black, with the exception of three large spots on each elytron of a beautiful straw colour: of these spots the first is humeral, transverse, and extends from the costal margin to the scutellum, but does not quite reach the base; the second is median, transverse, and reaches the costal but not quite the sutural margin ; the third is nearly apical, almost round, and does not reach either of the margins; the prothorax is rugose, and has five dorsal protuberances arranged thus, $\because$; the scutellum is elongate, linear, narrow, and has a longitudinal impression, it is of a clear pitchy black. This description was read before the Entomological Society of London, in 1839.

\section{Genus.-Lamia, Fabricius.}

Lamia ahenea. Nigra, lanugine lateritiâ undiquè tecta: elytra puncta, punctis à basi ad apicem magnitudine pedetentìm decrescentibus, ahenea, fasciâ angustâ posticè convexâ ante medium, vittâque laterali à medio ad apicem rufis: antennæ et tarsi glabra, nigra. (Corp. long. 1.5 unc. lat. 5 unc.)

Inhabits the Cape of Good Hope. There are two specimens in the cabinet of the Entomological Club.

\section{Genus.-Microcleptes, Newman.}

Caput pronum, prothorace vix angustius; facies complanata, lata, trigona: antennæ 11-articulatæ, corpore longiores, articulo basali majori ; oculi elongati, medio angustissimi : prothorax valdè convexus, lateribus rectis, spinâ acutâ armatis : elytra valdè convexa, humeris 1-dentata: pedes mediocres, femoribus tumidis, metafemora elytris longiora.

Micro. Aranea. Testaceo-fusca, puncta, punctis magnis, profundis, pravè dispositis, nunc distinctis, nunc confluentibus : facies et scutellum cinereo-tomentosa. (Corp. long. '225 unc. lat. '1 unc.) 
Inhabits South America. In the cabinet of the Entomological Society of London; taken by Mr. Darwin at Valparaiso. This little longicorn, which a good deal resembles a small brown spider, is very closely allied to the genera Compsosoma and Eusphærium, but appears to me sufficiently distinct from both.

\section{Genus.-Xylotoles, Newman.}

Caput pronum; antennæ corpore longiores, graciles, 11-articulatæ : prothorax ferè cylindraceus, capite triplò longior, lateribus rectus: elytra lateribus convexa, apice acuta: pedes mediocres, femoribus tumidis.

Xylo. lentus. Testaceo-fuscus : scutellum cinereo-lanuginosum, spatio mediano glabro: utrumque elytron maculis oblongis 6 obscurè flavido-lanuginosis signatum : elytra obsoletê 10-striata, striâ suturali cæteris distinctiori; versus elytrorum basim punctis nonnullis magnis profundis pravè dispositis. (Corp. long. $\cdot 4$ unc. lat. 15 unc.)

Inhabits New Zealand. A specimen in the cabinet of the Entomological Society of London was taken by Mr. Darwin.

\section{Genus.-Megacera, Serville.}

Mega. parvula. Antennæ corpore duplò longiores : prothorax capite angustior : puncta, elytrorum punctis profundis vix in ordine dispositis: testaceo-fusca, vittis 6 luteis capite prothoraci elytrisque communibus. (Corp. long. 3 unc. lat. 04 unc.)

Inhabits South America. A specimen in the cabinet of the Entomological Society of London, was taken by Mr. Darwin at Bahia. It differs but slightly from Megacera macrocera of Serville, except in size, being scarcely more than a seventh part as large ; the little projections on which the antennæ are situated are less prominent than in that species, and the extremities of the elytra less pointed and less divaricating.

\section{Genus.-SaPerda, Fabricius.}

Saper. cana. Nigra, lanugine canâ tecta: elytrorum lineâ suturali et marginali, sterno, abdomineque albidis. (Corp. long. 4 unc. lat. $\cdot 1$ unc.)

Inhabits North America. Two specimens in the cabinet of the Entomological Club, were taken by Mr. Doubleday at St. John's Bluff, East Florida. 
Saper. cinerea. Nigra, lanugine cinereâ densè tecta, lineâ longitudinali capitis prothoracisque albidâ. (Corp. long. 45 unc. lat. $\cdot 125$ unc.)

Inhabits Mexico. In the cabinet of the Entomological Club. This and the preceding species are very similar, but on comparison appear distinct : the present is the larger insect; its hue is rather ash-coloured than grey, and it wants the delicate sutural line of the elytra.

Saper. lata. Rufa : caput rufum, oculis antennisque nigris : prothorax rufus, maculis 4 dorsalibus nigris : elytra cana, margine laterali nigrâ : sternum nigrum, lanugine canâ tectum : abdomen rufum : pedes fusci, femoribus rufis. (Corp. long. 35 unc. lat. 1 unc.)

Inhabits Mexico. In the cabinet of the Entomological Club.

Saper. Alammata. Nigra, lanugine nigrâ densè tecta: antennæ hirsutæ, articulorum basis tenuissimè testaceus; caput ferrugineum, oculis maculâque verticali nigris : prothorax niger, lineâ latâ laterali ferrugineâ : elytra profundè puncta, lineâ tenuissimâ suturali alterâque costali ferrugineis. (Corp. long. 35 unc. lat. $\cdot 1$ unc.)

Inhabits North America. A specimen in the cabinet of the Entomological Club, was taken by Mr. E. Doubleday at St. John's Bluff.

Saper. juncea. Fusca; antennæ corpore longiores, fuscæ, articulorum omnium basis albidus; articulus apicalis totus albidus: prothorax cylindraceus, elongatus, angulis posticis valdè acutis: elytra elongata, linearia, apice obliquè truncata, puncta, punctis magnis biseriatìm dispositis, spatiis alternis paululùm elevatis : pedes breves ; metatarsi elytrorum apicem nullo modo attingentes. (Corp. long. 45 unc. lat. 075 unc.)

Inhabits Brazil. In the cabinet of the Entomological Club.

\section{Genus.-Phжа, Newman.}

Caput pronum; facies trigona; oculi 4, 2 rotundi, prominentes, laterales, 2 minores minùs prominentes, verticales; antennæ corpore manifestò breviores, 10 -articulatæ: prothorax inæqualis, dorso gibber, capite haùd latior: elytra linearia, prothorace paullò latiora, apicibus rotundatis : pedes breves, femoribus simplicibus. 
Phea Saperda. Rufa; oculis 4 nigerrimis; antennis apice fuscis : elytra nigra, basi rufa: cætera rufa: elytra profundè puncta, punctis vix lineatim dispositis. (Corp. long. 4 unc. lat. 1 unc.)

Inhabits Mexico. In the cabinet of the Entomological Club. In many of its characters this little insect nearly resembles the genus Tetraopes.

\section{Genus.-Callia, Serville.}

Callia axillaris. Antennæ nigræ; caput chalybeum : prothorax chalybeus, punctus : elytra nigro-purpurea, humeris ferrugineis, obscurè striata, striis subtillissimè punctis: abdomen et pedes chalybea. (Corp. long. 35 unc. lat. 15 unc.)

Inhabits Brazil. This pretty little insect, which occurs in every box of Brazilian insects, has long stood un-named in the cabinet of the Entomological Club. It appears to me to agree exactly with Serville's genus Callia.

\section{Natural Order.-Lepturites, Newman.}

\section{Genus.-Pytheus, Newman.}

Caput vix porrectum vix exsertum, oculi mediocres, laterales, ferè rotundi : antennæ dimidio corporis haùd longiores; articuli latitudine ferè æquantes; longitudine primo ultimoque exceptis crescentes: prothorax inermis, capite manifestò longior, medio paullò latior, lateribus anticè posticèque constrictis: elytra complanata carinata parallela apicibus inarmatis : pedes breves, femoribus apice tumidis.

Pytheus jugosus. Caput et prothorax rugata: elytra dorso complanata, jugosa, interstitiis profundè punctis, marginibus suturali et laterali elevatis, lineæ quoque 2 discoidales elevatæ in angulum analem desinent : caput, antennæ, prothorax, pro- meso- et metasternum coxæque nigra: elytra pedes et abdomen ferruginea; elytris maculâ communi dorsali alterâque apicali nigris. (Corp. long. 5 unc. lat. $\cdot 1125$ unc.)

Inhabits New Holland. In the cabinet of the Entomological Club, taken by Mr. Kirk near Sydney. 


\section{Natural Order-Clerites, Newman.}

It may be observed of all the Clerites yet discovered as inhabitants of New Holland, that they do not agree generically with those of Europe, and yet present few characters by which they can be made into new genera. Feeling a prejudice against encumbering the science with names, I have described them as belonging to Clerus as it stands in Dejean's 'Catalogue,' Clerus fasciculatus being the type.

\section{Genus.-Clerus, Fabricius.}

Clerus instabilis. Nitidus, pilosus, punctus, colore instabilis, nunc viridis, nunc violaceus : antennæ, protibiæ subtùs, protarsi omninò testacei. (Corp. long. 4 unc, lat. 15 unc.)

Inhabits New Holland. In the cabinet of the Entomological Club, taken by Mr. Davis, near Adelaide.

Clerus carus. Nitidus, subpilosus, elytrorum apicibus exceptis punctus, obscurè ferrugineus; elytris purpureis, fasciâ paullò post medium communi angustâ albidâ. (Corp. long. '2 unc. lat. 06 unc.)

Inhabits New Holland. In the cabinet of the Entomological Club, taken by Mr. Davis, near Adelaide.

Clerus crassus. Nitidus, pilosus, caput et prothorax subtilitèr puncta: elytrorum basis asperè ac profundè punctis, elytrorum apex glaberrimus : caput nigrum : prothorax ferrugineus : elytra basi chalybea, apice nigra, maculis utriusque transversis 3 albidis: abdomen pedesque chalybea. (Corp. long. 35 unc. lat. $\cdot 2$ unc.)

Inhabits New Holland. In the cabinet of the Entomological Club, taken by Mr. Imeson at Sydney.

Clerus splendidus. Nitidissimus, pilosus: caput subtilitèr punctum: prothorax rugosus, medio longitudinalitèr impressus: elytra apicibus præsertìm asperè ac profundè excavata: fuscoæneus, fulgore metallico lætus ; antennæ flavæ, scutellum aureovillosum: utriusque elytri maculâ ante, fasciâ post medium albidis signata: femora et tarsi subtùs testacea. Corp. long. ·5 unc. lat. $\cdot 1$ unc.

Inhabits New Holland. In the cabinet of the Entomological Club, taken by Mr. Davis, near Adelaide. 
Clerus simplex. Nitidus, pilosus, punctus, nigro-æneus : scutellum niveo-tomentosum: prothorax utrinquè anticè et posticè, metathorax utrinquè, segmentaque abdominis subtùs maculis niveo-tomentosis signata: antennæ ferrugineæ: femora pilis albidis obsita. (Corp. long. 45 unc. lat. $\cdot 125$ unc.)

Inhabits New Holland. In the cabinet of the Entomological Club, taken by Mr. Davis near Adelaide.

Clerus obscurus. Opacus, pilosus, punctus, niger, suprà tincturâ purpureâ, subtùs virescenti obscurè ornata: pectus et abdomen subtùs quoque femora pilis albis insita: scutellum et antennæ nigra. (Corp. long. 5 unc. lat. 125 unc.)

Inhabits New Holland. In the cabinet of the Entomological Club, taken by Mr. Davis near Adelaide.

Clerus pulcher. Nitidus, pilosus, punctus, nigro-æneus, fulgore instabili metallico lætissimus: antennæ fulvæ: scutellum pilis albis obsitum : utroque elytro maculâ magnâ medianâ fulvâ ornato: abdomen subtùs et femora pilis niveis passìm obsita; tibiæ et tarsi fusca. (Corp. long. 325 unc. lat. 11 unc.)

Inhabits New Holland. In the cabinet of the Entomological Club, taken by Mr. Davis, near Adelaide.

Clerus honestus. Nitidus, pilosus : prothorax punctus : elytra basi punctis profundis, magnis, confluentibus, rugosa; versus apicem lævigata; apice ipso lanugine argenteâ vestito: nigro-fuscus : antennæ testaceæ ; elytra fasciâ communi medianâ luteâ ornata; ante fasciam vestigiis testaceis obscuris signata; utroque elytro propè basim fasciculus dorsalis setarum nigrarum : femora fusca, tibiis tarsisque testaceis. (Corp. long. '6 unc. lat. $\cdot 175$ unc.)

Inhabits New Holland. In the cabinet of the Entomological Club, taken on Kanguroo Island. It has a very striking similarity to Clerus fasciculatus.

JOHN VAN VOORST,

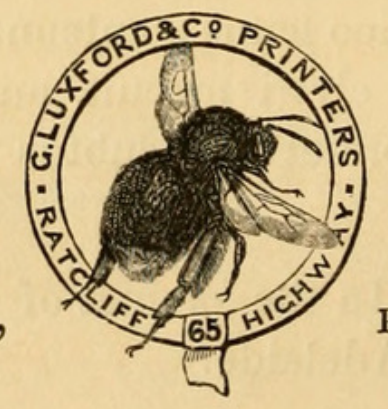

PATERNOSTER ROW. 


\section{$2 \mathrm{BHL}$ Biodiversity Heritage Library}

Newman, Edward. 1840. "Art. I. - Entomological Notes." The Entomologist 1, 1-16. https://doi.org/10.5962/bhl.part.9068.

View This Item Online: https://www.biodiversitylibrary.org/item/43668

DOI: https://doi.org/10.5962/bhl.part.9068

Permalink: $\underline{\text { https://www.biodiversitylibrary.org/partpdf/9068 }}$

\section{Holding Institution}

Smithsonian Libraries

\section{Sponsored by}

Smithsonian

\section{Copyright \& Reuse}

Copyright Status: NOT_IN_COPYRIGHT

This document was created from content at the Biodiversity Heritage Library, the world's largest open access digital library for biodiversity literature and archives. Visit BHL at https://www.biodiversitylibrary.org. 